\title{
Anti-IFNaR Mabs for the treatment of Systemic Lupus Erythematosus
}

Authors names and addresses:

Bethan Goulden MRCP

David Isenberg MD FRCP FAMS

The Centre for Rheumatology

University College Hospital

London

Contact Address for correspondence:

Professor David Isenberg

Rheumatology Department

The Rayne Building

5 University Street

University College London

London W1C1E 6JF

Telephone number: 02031082148

Email: d.isenberg@ucl.ac.uk 


\begin{abstract}
:
Introduction: The type 1 interferon pathway is known to play a role in the immunopathology of Systemic Lupus Erythematosus (SLE). As a result, biologic agents targeting this pathway have been developed and are currently being investigated in clinical trials.

Areas covered: We review the biologic agents which have been developed to antagonise type I interferons in SLE. We focus on anifrolumab, a type I interferon receptor antagonist, and consider the complexities of defining efficacy in SLE clinical trials.

Expert opinion: Anifrolumab shows promise as an addition to the SLE therapeutic armamentarium. Despite discordant results between its two phase III studies, there is a convincing suggestion of benefit in both trials to encourage the view that this approach might be effective. Data acquired thus far look particularly useful for cutaneous disease. We await data on its effect on renal, pulmonary, cardiac and central nervous system involvement, on patient reported outcomes, and its safety and efficacy with long term use.
\end{abstract}

Keywords: Anifrolumab, anti-interferon, interferon, Systemic Lupus Erythematosus, lupus activity

Article highlights box:

1. SLE continues to cause significant morbidity related to active disease, accrued damage and side-effects of traditional treatments such as corticosteroids and immunosuppressives

2. A high interferon gene signature is seen in the majority of adult patients with SLE

3. Biologic agents which antagonise type 1 interferons may be a future therapeutic option for SLE

4. The type 1 interferon receptor antagonist, anifrolumab, reported discordant results in two phase III trials

5. Further studies are required to establish the role of anifrolumab in clinical practice

1.0 Introduction:

Systemic Lupus Erythematosus (SLE) is a multi-system autoimmune rheumatic disease that typically presents in women of child-bearing age. It can affect all organs and systems and consequentially, there is considerable associated morbidity including changes in physical appearance, pain, pregnancy loss, and life changing organ damage such as renal failure [1]. A woman diagnosed with SLE in the 1950s had a $50 \%$ chance of survival at 4 years, whereas the 15 -year survival is now approximately $85 \%$ [2].

Cornerstones of treatment include corticosteroids, hydroxychloroquine, mycophenolate mofetil, azathioprine and methotrexate with the more recent addition of belimumab (anti-BAFF) [3] and rituximab (anti-CD20) [4]. However, high doses of steroids and immunosuppressives are associated with side effects including osteoporosis and infection [5]. Belimumab met its endpoints in large clinical trials $[6,7,8]$. In contrast evidence in favour of rituximab is derived from case series and registry data as two large randomised controlled trials failed to meet their primary endpoints (reviewed in [9]). Biologic agents which inhibit the type 1 interferons (IFN) or their receptor have shown promising, but discordant results in recent trials, highlighting the challenges faced by rheumatologists and the pharmaceutical industry in measuring efficacy in this condition.

\title{
1.1 Type 1 Interferons:
}

There are three different groups of IFNs - type 1, type 2 and type 3. Type 1 IFNs form an essential part of the anti-viral, innate immune response [10] but, inadvertently, also contribute to the immunopathology of SLE [11]. They encompass a group of structurally similar cytokines, the best described of which are IFN $\alpha$ and IFN $\beta$, though others including IFN- $\varepsilon$, IFN- $\omega$, IFN- - , IFN- $\delta$, IFN- $\tau$ and IFN- $\zeta$ are also recognised. Plasmacytoid dendritic cells (pDCs) are the primary source of type 1 IFNs, in addition to macrophages, fibroblasts and keratinocytes, though most nucleated cells have the 
potential to secrete them [12]. Secretion is typically triggered by infection, as pathogen recognition receptors (PRRs) on the cell surface or within endosomal compartments or the cytosol recognise microbial products such as viral DNA and RNA. Production of type 1 IFNs can then be significantly amplified as immune cells such as pDCs respond to this threat.

The type 1 IFNs signal via the type 1 IFN receptor (IFNAR) [13]. Signalling occurs on assembly of a ternary structure composed of subunits 1, 2, and one of the type 1 IFNs. This activates multiple downstream signalling pathways including the canonical Janus Kinase Signal Transducer and Activator of Transcription (JAK-STAT) pathway. First JAK1 and tyrosine kinase 2 (TYK2) are activated, and they then phosphorylate STAT1 and STAT2 which dimerise and translocate to the nucleus. This ultimately induces the transcription of hundreds of IFN stimulated genes (ISGs). This process can be quantified by measuring the transcription of these ISGs - a panel referred to as the IFN gene signature (IFNGS). This is however only one of the pathways by which type 1 IFNs mediate their effects, with the magnitude and nature of response varying dependent on factors such as cell type and infection. Furthermore, it is important to appreciate that the IFNGS is not a standardised measure and depending on the test used, the number and type of ISGs recognised can vary significantly. There is also evidence to suggest organ specific differences in the type of IFNs active within each tissue and as such, a peripheral measure (eg: whole blood) may not reflect the signature present within the kidney, skin or other active system [14]. To add further complexity, the signal itself is not solely a measure of type 1 IFNs due to an overlap in the genes induced by type 1, 2 and 3 IFNs [15].

The ultimate effect of the type 1 IFNs is to promulgate an anti-viral state in infected and neighbouring cells, modulate innate immune responses to promote antigen presentation whilst limiting pro-inflammatory cascades which could cause host injury, and activate the adaptive immune system to drive the production of high-affinity $\mathrm{T}$ - and B-cell responses and immunological memory [16]. The process which leads to attenuation and ultimately, termination of this response as a viral infection resolves remains poorly understood, as highlighted at the Inaugural Interferon Research Summit in 2017 [17].

\subsection{The role of Interferons in SLE:}

The IFNGS is overexpressed in $90 \%$ of children with SLE and up to $75 \%$ of adults with the disease and is higher in those with severe manifestations such as neuropsychiatric, haematological and renal involvement [11] (though interestingly, not necessarily correlating with higher disease activity or flare [18]). Genetic polymorphisms within type 1 IFN pathways are associated with an increased risk of developing SLE. There are also a series of monogenic, inheritable disorders with SLE-like features, such as Aicardi Goutières syndrome, which are collectively known as the interferonopathies and are characterised by overproduction of type 1 IFNs [19]. Causative mutations have been identified in the metabolism of nucleic acids, nucleic acid signalling, regulatory pathways and proteasome function. Furthermore, treatment with IFNa (for some forms of leukaemia, lymphoma, carcinoid tumours and viral hepatitis) is recognised as a potential cause of drug induced lupus (DIL) and one of the few forms of DIL that can trigger anti-dsDNA antibody production [20]. In addition, IFNa therapy also seems capable of precipitating cases of genuine SLE with more severe and multi-system involvement than is typically seen in DIL [21]. Long before these clinical observations, accelerated disease progression in the presence of type 1 IFNs had been described in murine models of SLE [22, 23].

It is thought that the key driver of the elevated IFNGS in SLE is the recognition of immune complexes containing endogenous nucleic acids by cells such as pDCs, which then cause persistent IFNa release and ultimately contribute to loss of tolerance to self and immunopathology [24]. The preceding events leading to this effect include cell death, cell damage and/or defective nucleic acid metabolism. In recent years, the process by which dying neutrophils release 'spider web' like fibres 
of chromatin called Neutrophil Extracellular Traps (NETs) has also been proposed as a possible step in SLE pathogenesis [25]. This process, termed NETosis, allows a final attempt by the cell to kill invading micro-organisms, but can also activate pDCs via PRRs such as TLR7/9 due to the presence of nuclear DNA, histones and granule proteins within the structure of the NET. Defective NETosis in patients with SLE may thus act as a further source of autoantigens. Furthermore, there is evidence to suggest that cells other than PDCs play a significant role in IFN release in SLE, including keratinocytes, monocytes and neutrophils; though further research is needed to elucidate their contribution [11].

This background sets the scene for an immunological milieu, in which there is increased stimulation of the immune system by self-antigens, coupled with dysregulation of normal regulatory breaks including within the IFN pathway. Given the role of type 1 IFNs this could drive persistent T and B cell stimulation with enhanced cell survival, autoantibody production, and further inflammatory mediator release. While parts of the story remain unexplained, biologics capable of suppressing type 1 IFNs or their receptor have become the focus of intense interest as novel therapeutic options for what remains a difficult disease to treat.

\subsection{Designing trials in SLE:}

Measuring efficacy in treatment trials for SLE has been a considerable barrier to many new medication successes over the years. Rituximab, widely accepted as a clinically useful biologic, failed to meet its primary endpoints in RCTs and its use in SLE is backed, as noted above, by case series and registry data [26]. A likely major contributor to the inability of clinical trials to show benefit is the use of concomitant medications, notably substantial doses of concomitant steroids (discussed by Isenberg and Ramos in [4]) which probably set the bar too high for rituximab (and other drugs too) to reach its primary endpoints. The other challenge is what measure of efficacy should be employed to determine trial endpoints.

In recent years, triallists have turned to combined efficacy measures which link the best-known activity indices - the SLE Disease Activity Index (SLEDAI) and British Isles Lupus Assessment Group (BILAG) with a physician's global score [27]. One such composite measure is the SLE Responder Index (SRI). Using this as its primary outcome measure, Belimumab became the first new SLE treatment to be approved in decades $[6,7,8]$. This is a composite measure which combines SELENA-SLEDAI, BILAG-2004 and Physician Global Assessment (PGA). The first is used to identify a global change in disease activity, the second captures more comprehensively change in specific organs and systems (filling some gaps such as gastrointestinal and ophthalmological disease not captured in the SLEDAI), and the last incorporates the physician's view, theoretically acting to validate and provide an overview for the SLEDAI and BILAG [28]. Meeting the SRI endpoint requires a reduction in a predefined number of points in SELENA-SLEDAI (4 points were originally chosen, in which case it is termed SRI(4)), no new BILAG A or no more than 1 new BILAG B score and no deterioration in baseline PGA score by 0.3 or more points. An alternative, though equally complex measure, is the BILAG based Composite Lupus Assessment (BICLA) which requires reduction in all baseline moderate to severe disease activity, no worsening in any of the 9 systems scored on BILAG 2004, no worsening of the SLEDAl, and no increase of 0.3 or more on physician global assessment.

The key difference in these composite measures is that the BICLA requires only partial improvement in activity, but in every affected organ/system, whereas SRI requires full improvement in some manifestations but not in all organs/systems. Since the success of Belimumab, trials have rapidly adopted these novel composite measures as their primary endpoint (usually with an additional requirement that no pre-defined restricted medications have needed to be used), but they arguably remain an imperfect measure of this heterogenous disease. 


\subsection{Blocking type 1 interferons in SLE:}

Biologics which directly inhibit IFN $\alpha$ or the type 1 IFN receptor have received much interest as a possible treatment option in SLE (see Table 1 for a summary of phase II and III trials of these agents). Anti-IFNa agents include rontalizumab [29], sifalimumab (previously called MEDI-345) [30] and AGS009 [31]. These have had minimal to modest effect in clinical trials.

AGS-009 is an anti-IFN $\alpha$ monoclonal antibody which was only trialled in a phase I study of 25 patients. It was assessed in individuals with mild to moderate SLE who were randomised 3:1 to a single intravenous (IV) infusion of AGS-009 at 0.01, 0.1, 0.6, 3, 10 and 30mg/kg versus placebo. The primary endpoints were safety, pharmacokinetics and capacity to neutralise the IFNGS. It was deemed to be safe and well tolerated with dose related suppression of the IFNGS but no further studies have taken place to determine clinical efficacy.

In contrast, sifalimumab, a fully human, monoclonal anti-IFNa was assessed in a phase II trial of 431 patients with moderate to severe SLE who received monthly IV sifalimumab at 200mg, 600mg or $1200 \mathrm{mg}$ dosing or placebo. Groups were stratified immunologically, on low or high IFNGS, and geographically. The primary endpoint was SRI(4) at week 52. This effect was met across all 4 dosage groups, but only met statistical significance in the highest dosing group. In those receiving $1200 \mathrm{mg}$ IV monthly of sifalimumab, $59.9 \%$ met the primary endpoint versus $45.4 \%$ in placebo $(p=0.031)$, and there were also positive effects seen in Cutaneous Lupus Erythematosus Disease Area and Severity Index (CLASI), Physician Global Assessment and BICLA. On further analysis a greater distinction from placebo was seen in those with a high IFNGS at baseline.

Finally, rontalizumab is a humanised, monoclonal anti-IFN $\alpha$ which was assessed in the phase II ROSE trial. 238 patients were randomised 2:1 to receive either $750 \mathrm{mg}$ IV rontalizumab monthly or placebo in part 1 , followed by $300 \mathrm{mg}$ subcutaneous (SC) rontalizumab every 2 weeks or placebo in part 2 . Unlike other major trials, this assessed the treatment as a replacement therapy rather than add-on option. Thus, whilst steroids and hydroxychloroquine were allowed, they restricted the use of mycophenolate mofetil, azathioprine and cyclophosphamide. The primary endpoint was step-down improvement in BILAG score at week 24, with no new A or $>1$ new B score and no use of restricted medications. This was achieved in $45.5 \%$ of the pooled treatment groups (IV and SC) versus $41.8 \%$ of those in the placebo group (difference $3.5 \%, 95 \% \mathrm{Cl}-7.2-14.3 \% ; p=0.6$ ). No meaningful differences in response were identified between those with a high or low IFNGS at baseline.

\subsection{Blocking the type 1 interferon receptor in SLE:}

It was hypothesised that a more clinically efficacious approach might be to target IFNAR and thereby inhibit the actions of all type 1 IFNs at their target receptor, rather than IFN $\alpha$ alone. Anifrolumab, previously known as MEDI-546, is an antibody against IFNAR subunit 1 which showed promise in a phase II, randomised, double blind, placebo-controlled trial. In patients with moderate to severe SLE it was demonstrated that it reduced disease activity compared to placebo based on SRI(4) at week 24 with a sustained reduction in oral corticosteroid dose [32]. It has since undergone two phase III trials - Treatment of Uncontrolled Lupus via the Interferon Pathway-1 (TULIP-1) [33] and 2 (TULIP-2) [34] which reported in 2019 and 2020, respectively. Related ongoing studies include the TULIP long term extension study (TULIP-LTE; NCT02794285) and TULIP-lupus nephritis (TULIP-LN; NCT02547922) which is a phase II trial looking at those with renal involvement.

TULIP-1 and TULIP-2 were large, randomised, placebo-controlled trials, comprising in total over 800 adult patients with moderate to severe active, seropositive SLE on standard of care treatment; excluding those with active renal and/or neuropsychiatric SLE. Both had stratified randomisation according to SLEDAI score at screening $(<10$ or $\geq 10)$, baseline glucocorticoid dose $(<10 \mathrm{mg} /$ day or $\geq 10 \mathrm{mg} /$ day of prednisolone or equivalent) and type I IFNGS (high or low). All patients on $\geq 10 \mathrm{mg} /$ day 
of prednisolone or equivalent at baseline had to attempt a steroid taper from week 8. They differed at baseline in the inclusion of both a $150 \mathrm{mg}$ IV anifrolumab and $300 \mathrm{mg}$ IV anifrolumab dose in TULIP1 , whilst only the $300 \mathrm{mg}$ IV dose was included in TULIP-2. Crucially, TULIP-2 also made significant protocol amendments during the trial. Whilst both trials initially had SRI(4) as the primary endpoint, after the results of TULIP-1 were analysed, but prior to the unblinding of TULIP-2 outcomes, the primary endpoint of TULIP-2 was changed to BICLA response at 52 weeks and NSAIDs were removed from the restricted medication list. Intriguingly, whereas TULIP-1 failed to meet its primary endpoint, TULIP-2 met it and demonstrated clinically meaningful and statistically significant effects from anifrolumab treatment. Ironically, TULIP-2 also ultimately met the SRI-4 end point.

In TULIP-2, $47 \%$ of patients were on $>10 \mathrm{mg}$ prednisolone a day at baseline, and $48 \%$ were taking other forms of immunosuppression. Around $10 \%$ of patients were Black. $83 \%$ had a high interferon gene signature. A BICLA response at week 52 was seen in $47.8 \%$ receiving anifrolumab $300 \mathrm{mg}$ IV and $31.5 \%$ receiving placebo (difference $16.3,95 \% \mathrm{Cl} 6.3-26.3 ; \mathrm{p}=0.001$ ). When the group with a high IFN gene signature were looked at specifically, $48 \%$ had a BICLA response with anifrolumab compared to $30.7 \%$ in the placebo group (difference $17.3 \%, 95 \% \mathrm{Cl} 6.5-28.2 ; \mathrm{p}=0.02$ ). $51.5 \%$ of those on $>10 \mathrm{mg}$ of prednisolone at baseline were able to reduce this to $<7.5 \mathrm{mg}$ in the treatment group compared to just $30.2 \%$ in the placebo group (difference $21.2 \%, 95 \% \mathrm{Cl} 6.8-35.7 ; \mathrm{p}=0.01$ ). SRI(4) was achieved by $55.5 \%$ of the treatment group and $37.3 \%$ of the placebo group (unadjusted $p=<0.001$ ).

The decision to remove NSAIDs from the restricted medication list was borne out of the observation that in TULIP-1, 8\% of patients took NSAIDs during the trial (not necessarily for lupus) and this classified them as a medication non-responder. With regards to the decision to change the primary endpoint, the supplementary appendix of TULIP-2 argues that "the lack of gold standard for efficacy measurement in SLE, combined with the urgent unmet need for SLE treatments and the potential for anifrolumab to benefit patients with SLE" was their trigger for the endpoint switch, given the disappointing results from TULIP-1. Clinically meaningful changes in BICLA were demonstrated in other anifrolumab studies and it was a clinically and scientifically acceptable alternative composite measure of SLE activity. No data from TULIP-2 was utilised to guide this decision and the results remained blinded at the time of the change. Given that the SLEDAI component of the SRI requires complete improvement in organ systems, there was also a concern that a clinically meaningful, partial reduction in activity across one or many systems would be missed and that the BILAG component of BICLA was able to account for this more accurately.

\subsection{Skin disease:}

Both the SELENA-SLEDAI and BILAG include measures of cutaneous involvement, but the secondary endpoints of MUSE, TULIP-1 and TULIP-2 also looked at anifrolumab efficacy using a dedicated activity score known as the Cutaneous Lupus Erythematous Disease Area and Severity Index (CLASI) [35]. Developed in 2005, it aims to account for both established damage and active cutaneous SLE, a crucial step for correctly determining treatment effect in a clinical trial setting. Active disease is identified by the presence of erythema, scale and hypertrophy, in contrast to damage which is characterised by dyspigmentation, scarring and atrophy. Points are also allocated for mucous membrane involvement and alopecia. Validation studies confirm that it is responsive to changes in cutaneous disease activity and damage, and correlates with physician assessed cutaneous disease activity and patient-reported health outcomes [36]. For those patients with at least moderately active cutaneous disease at baseline, a $50 \%$ reduction in CLASI was the chosen secondary endpoint in all three of the major anifrolumab trials. In MUSE this was assessed at week 52 and met in $63 \%$ of those on anifrolumab $300 \mathrm{mg}$ compared to just $30.8 \%$ in the placebo arm $(p=0.013)$. In TULIP-2, this was met at 12 weeks in $49 \%$ of patients receiving anifrolumab and $25 \%$ receiving placebo, a difference of $24 \%$ (95\% $\mathrm{Cl} 4.3-43.6 ; \mathrm{p}=0.04)$. Similar findings were reported in TULIP-1. 
The promising effects of anifrolumab on skin disease in SLE have underlying biological plausibility. Affected skin shows accumulation of pDCs which secrete IFN $\alpha / \beta$ and increased expression of IFN gene-regulated transcripts and proteins [37,38]. Furthermore, a higher IFNGS is seen in patients with cutaneous forms of lupus (subacute cutaneous lupus erythematosus and discoid lupus erythematosus) and levels correlate with cutaneous disease activity [39].

\subsection{Joint disease:}

Unlike the robust signal of benefit for anifrolumab on cutaneous disease in all three trials, the signal for arthritis was less consistent. In MUSE and TULIP-1 the relevant secondary endpoint was defined as those with $\geq 50 \%$ reduction in active joints at week 52 among those who had $\geq 8$ swollen and $\geq 8$ tender joints at baseline, whilst in TULIP-2 the baseline value was $\geq 6$ swollen and $\geq 6$ tender joints. In MUSE this was achieved in $48.6 \%$ of the placebo group and $69.6 \%$ of the anifrolumab $300 \mathrm{mg}$ group $(p=0.038)$. In TULIP-1 it was achieved in $32 \%$ of the placebo group and $53 \%$ of the anifrolumab $300 \mathrm{mg}$ group (difference 20.7\%; 95\% Cl 4.7-36.7; p=not documented). However, in TULIP-2, with the slight adjustment to the number of active joints, $37.5 \%$ of the placebo group and $42.2 \%$ of the anifrolumab 300mg group met the endpoint (difference 4.7\%; $95 \% \mathrm{Cl}-10.6-20 ; \mathrm{p}=0.55$ ).

In a post-hoc analysis of the MUSE trial, examining the differences between the high and low IFNGS groups, it was found that the mean difference between treatment and placebo groups in active joint counts were comparable regardless of gene expression level and was not statistically significant. Furthermore, whilst the $50 \%$ reduction in joint count detected a difference between placebo and treatment group, the SLEDAI measure of arthritis did not [40]. This is likely to be because SLEDAI requires complete resolution of arthritis.

The role for IFNs in arthritis is less clear cut than that described above for cutaneous disease and the discrepancies between trials may reflect this. It could be hypothesised that the IFNGS measured in the blood does not reflect joint level IFN activity, or that other cytokines have a more dominant effect on the articular involvement seen in SLE. One small study of 6 six patients with SLE who had knee swelling identified significant up-regulation of the IFNGS in synovial biopsies, but given the small numbers and relatively uncommon finding of knee swelling in SLE patients (versus swelling of the small joints of the hands) we should question the widespread applicability of these results [41]. No paired peripheral blood samples were analysed.

\subsection{Administration:}

Phase II and III trials have studied 150mg, 300mg and 1000mg IV anifrolumab given once every 4 weeks. A single phase II trial looked at SC administration of anifrolumab at doses of $150 \mathrm{mg}$ or $300 \mathrm{mg}$ every 2 weeks with a comparable pharmacokinetic profile and clinical effect to the IV formulation [42]. The 300mg IV dosing was chosen for TULIP-2 - demonstrating a similar treatment effect and suppression of IFNGS to the $1000 \mathrm{mg}$ dose but with fewer adverse events in analysis from previous trials [43].

\subsection{Adverse effects:}

Given the role of type 1 IFNs in anti-viral immunity, it is not surprising that trials reported a higher incidence of varicella zoster virus (VZV) re-activation, in addition to influenza, bronchitis, and upper respiratory tract infections. For VZV infection, this was shown to be a dose related effect with higher rates in those treated with $1000 \mathrm{mg} I V$ anifrolumab versus $300 \mathrm{mg}$ IV anifrolumab in the MUSE trial. This trial also recorded a case of transverse myelitis with positive VZV PCR on cerebrospinal fluid analysis. Multi-dermatomal shingles is noted with anifrolumab. In TULIP-2, 3 cases of tuberculosis were seen in the treatment group despite screening at baseline, and one death occurred secondary to pneumonia. A further death secondary to pneumonia was seen in the $300 \mathrm{mg}$ group of TULIP-1. 
In TULIP-1 4-6\% of the treatment groups experienced a hypersensitivity reaction, and $2 \%$ developed anti-drug antibodies. In TULIP-2, hypersensitivity reactions were recorded in $1.1 \%$ and only 1 patient developed anti-drug antibodies during the trial period.

At present, we have no data to guide the use of anifrolumab in children, pregnant women, those with severe/active neuropsychiatric, lung, heart or renal involvement, or following the recent use of belimumab, rituximab (and other anti-CD20 agents), or cyclophosphamide. As an IgG1 molecule, anifrolumab would be anticipated to have active placental transfer to the foetus, especially in the later stages of pregnancy, and as such, if this were to be utilised in pregnant women, studies assessing the magnitude of transfer and implications on the foetal immune system, infectious complications, vaccine responses and safety are necessary to clarify more widespread use. Equally, given that high IFN $\alpha$ may correlate with pre-eclampsia risk in the pregnancies of women with SLE due to its anti-angiogenic roles, recording any beneficial impacts on pregnancy outcomes could also be insightful [44].

Viral genes which impair the human type 1 IFN response have already been shown to have contributed to the virulence of the 1918 Spanish flu pandemic, which claimed the lives of an estimated 50 million people [45]. With this in mind, the impact of a biologic such as anifrolumab on Covid-19 morbidity and mortality must also be considered. Recombinant type 1 IFN has been trialled in patients with Covid-19 following the finding of an impaired type 1 IFN response in those with severe disease [46]. Whilst viral evasion may contribute to this impairment, it has also been shown that almost $15 \%$ of those with life-threatening Covid-19 have inborn errors of [47], or autoantibodies to [48], type 1 IFNs. It is hypothesised that early impairment of the type 1 IFN response enables higher levels of SARS-CoV2 replication, which contributes to hypercytokinaemia with elevated levels of interleukin- 6 and tumour necrosis factor- $\alpha$ contributing to host damage. To complicate matters, other studies also demonstrate a high IFNGS in the bronchoalveolar lavage fluid of those with Covid-19 [49] and JAK-inhibitors which suppress the type 1 IFN response are also under investigation as a potential treatment in those with severe disease [50]. Timing may therefore be important when considering the risk of anifrolumab in the context of this global pandemic. It suggests that further impairment of type I IFN response in early disease could increase the risk of progression to severe Covid-19 and thus caution should be exercised with its use. This potential biphasic profile of risk correlates with the finding in the Covid-19 Global Rheumatology Alliance register that prednisolone $>10 \mathrm{mg} /$ day at time of initial infection is associated with an increased risk of hospitalisation [51] but that the Randomised Evaluation of COVid-19 thERapY (RECOVERY) trial showed that the use of dexamethasone in those who progress to requiring supplemental oxygen or invasive mechanical ventilation reduces 28 -day mortality [52].

\subsection{Changes in laboratory parameters:}

MUSE, TULIP-1 and TULIP-2 all utilised the same 4 gene panel of type 1 IFN regulated genes as its measure of the IFNGS, consisting of IFI27, IFI44, IFI44L and RSAD2. 83.1\% of patients in TULIP-2 had a high IFNGS at baseline, which is a relatively high percentage for a population of adult patients with SLE in comparison to other studies in the literature. There was early and sustained neutralisation of the IFNGS with anifrolumab, but no statistically significant differences in anti-dsDNA antibody and complement levels between treatment and placebo groups.

A 2020 study of 31 patients with childhood onset SLE demonstrated that a high IFNGS was associated with normocomplementaemia and less severe disease [53]. In an adult population of 243 patients with SLE, a higher IFNGS was associated with worse cutaneous and musculoskeletal disease activity, higher anti-dsDNA antibody levels and lower complement levels [18]. Numerous studies have shown that whilst the IFNGS can select out a group of patients with worse disease, within an individual patient, the IFNGS does not correlate with changes in disease activity. Thus, the lack of 
statistically significant change between serological SLE markers in the TULIP trials is perhaps not surprising.

There has been some interest in whether pre-screening IFNGS would allow the identification of a cohort of patients more likely to benefit from anti-IFN therapy. In TULIP-2, the subpopulation with a high IFNGS met BICLA response at week 52 in $48 \%$ of the anifrolumab group versus $30.7 \%$ of the placebo group (difference 17.3\%; 95\% Cl 6.5-28.2\%; p=0.002). In contrast those with a low IFNGS met BICLA response at week 52 in $46.7 \%$ of the anifrolumab group, and $35.5 \%$ of the placebo group (difference $11.2 \%$; $95 \% \mathrm{Cl}-13.5-35.8 \%$ ). In TULIP-1, among those with a high IFNGS receiving $300 \mathrm{mg}$ anifrolumab, SRI(4) response at week 52 was $36 \%$ versus $39 \%$ in the placebo group (difference $3.4 \% ; 95 \% \mathrm{Cl}-14.4-7.6 \%$ ). In MUSE, the overall positive outcome appeared to be driven by marked beneficial effect in the high IFNGS subgroup.

3.0 Conclusion:

TULIP-1 and -2 were large, multi-centre, cross-continent trials, and the patient population studied clearly captured the target population for a novel add-on therapeutic agent - that is, predominantly females of childbearing age, albeit with a minority of patients of Black and Asian ethnicity, but with active disease despite standard of care therapy and a high burden of steroid use. The key finding in TULIP-2 that patients were able to wean steroids successfully whilst on anifrolumab is of benefit given their contribution to SLE related morbidity and mortality. While studies have largely looked at IV dosing, the prospect of a SC biologic for SLE would be a welcome addition to the SLE armamentarium. Anifrolumab has shown particularly promising results in those with cutaneous SLE, but further studies such as TULIP-LN should provide clarification about its effectiveness in lupus nephritis. Reviewing the data thus far, it is not clear that this is a treatment that should be restricted to those with a high IFNGS at baseline, though some of the data would support this idea. Further clinical and trial experience should help clarify its overall utility, if any, in a low IFNGS cohort. The fact that not all patients respond to anifrolumab is likely to be multifactorial, related to the pharmacodynamics of the biologic itself and heterogeneity in the immunopathology between patients and different organ systems, including the possible role of other IFN pathways such as that of the type III IFNs.

\subsection{Expert opinion:}

After the successful phase II MUSE trial, there was undeniable disappointment that this success had not extended to the first phase III TULIP-1 trial. Nevertheless, the decision to alter the endpoint of TULIP-2 was somewhat controversial and attracted opinion pieces discussing its merits and validity $[54,55]$. SRI(4) was a natural first choice endpoint given that it showed consistent success in four phase III trials of Belimumab. However, our understanding of the relative merits of the various composite scores remains incomplete. Inconsistency in trial results of medications with biological plausibility for effect and many positive secondary endpoints, such as that seen with anifrolumab, only adds to the uncertainty of what "efficacy" really is in SLE treatment trials. Ultimately, the benefit seen with BICLA in TULIP-1 was reproduced in TULIP-2 with a clinically and statistically significant response. The protocol amendment that removed NSAIDs from the restricted medication list is a reasonable one given that this included patients using NSAIDs for non-SLE reasons.

Furthermore, in clinical practice an increase in NSAID use alone would not necessarily be interpreted as a failure of the current therapy necessitating treatment switch or escalation. The fact that SRI(4) indicated a positive treatment effect for anifrolumab in TULIP-2 is also reassuring.

It has been highlighted that despite collecting data on patient reported outcomes (PROs), the publication of the results of this aspect of TULIP-2 is still awaited [56]. The simple question of whether a medication makes our patients feel better is an essential one, and the disconnect between patient and physician perception of SLE activity and morbidity is well documented $[57,58]$. 
We hope that the data will be released soon, noting the suggestion of benefit recorded in the MUSE trial in PROs such as FACIT-F and SF-36 (although these did not meet clinical significance).

Given the typical demographic of SLE patients, any agent that is authorised for clinical use is likely to end up being used, be that inadvertently or not, in pregnant women or shortly before conception regardless of advice to the contrary. This reflects unplanned pregnancies and pregnancies in those women for whom the benefits of using the biologic to control disease activity, particularly in the first and/or second trimester, is deemed to outweigh theoretical risks. New FDA rules in place since 2015 mean that applications for drug approvals must provide pregnancy and lactation information for the label, including the details of any existing pregnancy registry [59]. A pregnancy registry would be a most useful contribution to the post-approval process for anifrolumab given the lack of pre-existing human or animal data for medications of this class. Likewise, additional information on the use of anifrolumab in larger numbers of patients from diverse ethnic groups is also needed. As discussed in section 2.5, the risks of contracting Covid-19 whilst on anifrolumab are yet to be elucidated but there is biological plausibility for concern and this should be monitored closely going forward.

If anifrolumab is authorised for commercial use in SLE then attempts at using it in other conditions characterised by a high IFNGS are likely to follow suite (eg: Rheumatoid Arthritis, Sjogren's Syndrome, Systemic Sclerosis, and Dermatomyositis) [60]. A phase IIA clinical trial in Rheumatoid Arthritis is already in progress and due to complete in March 2021 (NCT03435601). Furthermore, its success would also heighten interest in other agents active within this pathway for SLE, including the janus-kinase inhibitors (eg: baricitinib, tofacitinib) [61], IFN $\alpha$ kinoids (an intramuscularly administered vaccine that triggers the development of neutralising anti-IFN $\alpha$ antibodies) [62] and anti-BDCA2 (a monoclonal antibody against a pDC specific receptor which inhibits the secretion of type 1 IFN and other inflammatory mediators from these key cells) [63]. A schematic of the cellular targets of each of these agents, as well as anifrolumab and the anti-IFN $\alpha$ agents can be found in Figure 4 of Oon $\mathrm{S}$ et al. [64].

Pooled data for anifrolumab from TULIP-1 and TULIP-2 was presented at the EULAR 2020 E-Congress and focused on the beneficial effect on BICLA response and oral corticosteroid reduction [65]. Whether the Food and Drug Administration (FDA) and European Medicines Agency (EMA) approve it for SLE remains to be seen but promising results in its flagship trials certainly make it an attractive future treatment option for the condition, particularly if data from TULIP-LTE and TULIP-LN show ongoing and additional benefits.

References:

[1] Gordon C, Amissah-Arthur MB, Gayed M, et al. The British Society for Rheumatology guideline for the management of systemic lupus erythematosus in adults. Rheumatology (Oxford). 2018;57(1):e1e45. (* - a comprehensive data driven exercise exploring optimal SLE management)

[2] Tektonidou MG, Lewandowski LB, Hu J, et al. Survival in adults and children with systemic lupus erythematosus: a systematic review and Bayesian meta-analysis of studies from 1950 to 2016. Ann Rheum Dis. 2017;76(12):2009-2016.

[3] Blair H, Duggan S. Belimumab: A review in systemic lupus erythematosus. Drugs. 2018;78(3):355366.

[4] Ramos L, Isenberg D. Rituximab: The Lupus Journey. Curr Treatm Opt in Rheumatol. 2015;1:3041.

[5] Ruiz-Irastorza G, Danza A, Khamashta M. Glucocorticoid use and abuse in SLE. Rheumatology (Oxford). 2012;51(7):1145-1153. 
[6] Zhang F, Bae SC, Bass D, et al. A pivotal phase III randomised, placebo-controlled study of Belimumab in patients with systemic lupus erythematosus located in China, Japan and South Korea. Ann Rheum Dis. 2018;77(3):355-363.

[7] Furie R, Petrie M, Zamani O, et al. A Phase 3, Randomised, Placebo-Controlled Study of Belimumab, a Monoclonal Antibody That Inhibits BLyS, in Patients With Systemic Lupus Erythematosus. Arthritis Rheum. 2011;63(12):3918-3930.

[8] Navarra SV, Guzmán RM, Gallacher AE, et al. Efficacy and safety of belimumab in patients with active systemic lupus erythematosus: a randomised, placebo-controlled, phase 3 trial. Lancet. 2011;377(9767):721-731.

[9] Murphy G, Isenberg A. New therapies for systemic lupus erythematosus - past imperfect, future tense. Nat Rev Rheumatol. 2019; 15(7):403-412. (* - a recent critical review of potential new therapies for SLE)

[10] McNab F, Mayer-Barber K, Sher A, et al. Type I interferons in infectious disease. Nat Rev Immunol. 2015;15(2):87-103.

[11] Rönnblom L, Leonard D. Interferon pathway in SLE: one key to unlocking the mystery of the disease. Lupus Sci Med. 2019;6(1):e000270. (* - a timely review exploring the role of interferons in SLE)

[12] Eloranta ML, Alm, GV, Rönnblom L. Disease mechanisms in rheumatology - tools and pathways: plasmacytoid dendritic cells and their role in autoimmune rheumatic diseases. Arthritis Rheum. 2013;65(4):853-863.

[13] Platanias LC. Mechanisms of type-I- and type-II-interferon-mediated signalling. Nat Rev Rheumatol. 2005;5(5):375-386.

[14] Sarkar MK, Hile GA, Tsoi LC, et al. Photosensitivity and type I IFN responses in cutaneous lupus are driven by epidermal-derived interferon kappa. Ann Rheum Dis. 2018;77(11):1653-1664.

[15] Rönnblom L, Eloranta ML. The interferon signature in autoimmune diseases. Curr Opin Rheumatol. 2013;25(2):248-253.

[16] Ivashkiv LB, Donlin LT. Regulation of type I interferon responses. Nat Rev Immunol. 2014;14(1):36-49.

[17] Crow M, Rönnblom L. Report of the inaugural Interferon Research Summit: interferon in inflammatory diseases. Lupus Sci Med. 2018;5(1):e000276.

[18] Petri M, Fu W, Ranger A, Allaire N, et al. Association between changes in gene signatures expression and disease activity among patients with systemic lupus erythematosus. BMC Med Genomics. 2019;12(1):4.

[19] Eleftheriou D, Brogan PA. Genetic Interferonopathies: An overview. Best Pract Res Clin Rheumatol. 2017;31(4):441-459.

[20] Arnaud L, Mertz P, Gavand PE, et al. Drug-induced systemic lupus: revisiting the ever-changing spectrum of the disease using the WHO pharmacovigilance database. Ann Rheum Dis. 2019;78(4):504-508.

[21] Niewold T. Interferon Alpha-Induced Lupus Proof of Principle. J Clin Rheumatol. 2008;14(3):131132.

[22] Adam C, Thoua $Y$, Ronco $P$, et al. The effect of exogenous interferon: acceleration of autoimmune and renal diseases in (NZB/W) F1 mice. Clin Exp Immunol. 1980;40(2):373-82.

[23] Heremans H, Billiau A, Colombatti A, et al. Interferon treatment of NZM mice: accelerated progression of autoimmune disease. Infect Immun. 1978;21(3):925-930.

[24] Rönnblom L, Alm GV. The natural interferon-alpha producing cells in systemic lupus erythematosus. Hum Immunol. 2002;63(12):1181-1193.

[25] Salemme R, Peralta LN, Meka SH, et al. The Role of NETosis in Systemic Lupus Erythematosus. J Cell Immunol. 2019;1(2):33-42.

[26] McCarthy EM, Sutton E, Nesbit S, et al. Short-term efficacy and safety of rituximab therapy in refractory systemic lupus erythematosus: results from the British Isles Lupus Assessment Group Biologics Register. Rheumatology (Oxford). 2018;57(3):470-479. 
[27] Thanou A, Chakravarty E, James J, et al. Which outcome measures in SLE clinical trials best reflect medical judgement? Lupus Sci Med. 2014;1(1):e000005. (* - thoughtful analysis of SLE clinical trial endpoints)

[28] Luijten KMAC, Tekstra J, Bijlsma JWJ, et al. The Systemic Lupus Erythematosus Responder Index (SRI); a new SLE disease activity assessment. Autimmun Rev. 2012;11(5):326-329.

[29] Kalunian K, Merrill JT, Maciuca R, et al. A Phase II study of the efficacy and safety of rontalizumab (rhuMAb interferon- $\alpha$ ) in patients with systemic lupus erythematosus (ROSE). 2016;75(1):196-202.

[30] Khamashta M, Merrill JT, Werth VP, et al. Sifalimumab, an anti-interferon- $\alpha$ monoclonal antibody, in moderate to severe systemic lupus erythematosus: a randomised, double-blind, placebo-controlled study. Ann Rheum Dis. 2016;75(11):1909-1916.

[31] Tcherepanova I, Curtis M, Sale M, et al. Results of a randomised placebo controlled phase la study of AGS-009, a humanised anti-interferon- $\alpha$ monoclonal antibody in subjects with systemic lupus erythematosus. Ann Rheum Dis. 2013;71:536-537.

[32] Furie R, Khamashta M, Merrill JT, et al. Anifrolumab, an Anti-Interferon- $\alpha$ Receptor Monoclonal Antibody, in Moderate-to-Severe Systemic Lupus Erythematosus. Arthritis Rheumatol.

2017;69(2):376-386. ( ${ }^{*}$ - first demonstration of the potential utility of anifrolumab)

[33] Furie R, Morand EF, Bruce IN, et al. Type I interferon inhibitor anifrolumab in active systemic lupus erythematosus (TULIP-1): a randomised, controlled, phase 3 trial. Lancet Rheum.

2019;1(4):E208-E219.(* - phase III trial of anifrolumab in SLE, did not meet primary endpoint)

[34] Morand EF, Furie R, Tanaka Y, et al. Trial of Anifrolumab in Active Systemic Lupus

Erythematosus. N Engl J Med. 2020;382(3):211-221. (** phase III trial of anifrolumab in SLE, did meet its primary endpoint)

[35] Albrecht J, Taylor L, Berlin JA, et al. The CLASI (Cutaneous LE Disease Area and Severity Index): an outcome instrument for cutaneous lupus erythematosus. J Invest Dermatol. 2005;125(5):889-894. [36] Jolly M, Kazmi N, Mikolaitis R, et al. Validation of the Cutaneous Lupus Disease Area and Severity Index (CLASI) using physician- and patient-assessed health outcome measures. J Am Acad Dermatol. 2013;68(4):618-623.

[37] Farkas L, Beiske K, Lund-Johansen F, et al. Plasmacytoid dendritic cells (natural interferonalpha/beta-producing cells) accumulate in cutaneous lupus erythematosus lesions. Am J Pathol. 2001;159(1):237-243.

[38] Wenzel J, Wörenkämper E, Freutel S, et al. Enhanced type I interferon signalling promotes Th1biased inflammation in cutaneous lupus erythematosus. J Pathol. 2005;205(4):435-442.

[39] Braunstein I, Klein R, Okawa J, et al. The interferon-regulated gene signature is elevated in subacute cutaneous lupus erythematosus and discoid lupus erythematosus and correlates with the cutaneous lupus area and severity index score. Br J Dermatol. 2012;166(5):971-975.

[40] Merrill JT, Furie R, Werth VP, et al. Anifrolumab effects on rash and arthritis: impact of the type I interferon gene signature in the phase IIb MUSE study in patients with systemic lupus erythematosus. Lupus Sci Med. 2018;5(1):e000284.

[41] Nzeusseu Toukap A, Galant C, Theate I, et al. Identification of distinct gene expression profiles in the synovium of patients with systemic lupus erythematosus. Arthritis Rheum. 2007;56(5):15791588.

[42] Bruce I, Nami A, Schwetje E, et al. PK/PD, Safety and Exploratory Efficacy of Subcutaneous Anifrolumab in SLE: A Phase-II Study in Interferon Type I High Patients with Active Skin Disease [abstract]. Arthritis Rheumatol. 2019;71.

[43] Brohawn P, Santiago L, Morehouse C, et al. Target modulation of a Type I Interferon Gene Signature and Pharmacokinetics of Anifrolumab in a Phase Ilb Study of Patients with Moderate to Severe Systemic Lupus Erythematosus [abstract]. Arthritis Rheumatol. 2015;67.

[44] Andrade D, Kim M, Blanco LP, et al. Interferon- $\alpha$ and angiogenic dysregulation in pregnant lupus patients destined for preeclampsia. Arthritis Rheumatol. 2015;67(4):977-987. 
[45] Billharz R, Zeng H, Proll S, et al. The NS1 protein of the 1918 pandemic influenza virus blocks host interferon and lipid metabolism pathways. J Virol. 2009;83(20):10557-10570.

[46] Lee JS, Shin EC. The type I interferon response in COVID-19: implications for treatment. Nat Rev Immunol. 2020;20(10):585-586.

[47] Zhang Q, Bastard P, Liu Z, et al. Inborn errors of type I IFN immunity in patients with lifethreatening COVID-19. Science. 2020 [cited 2020 Sept 27]; [22 p.]. DOI:10.1126/science.abd4570 [48] Bastard P, Rosen LB, Zhang Q, et al. Auto-antibodies against type I IFNs in patients with lifethreatening COVID-19. Science. 2020 [cited 2020 Sept 27]; [18 p.]. DOI:10.1126/science.abd4585 [49] Zhou Z, Ren L, Zhang L, et al. Heightened innate immune responses in the respiratory tract of COVID-19 patients. Cell Host Microbe. 2020;27(6):883-890.

[50] Luo W, Lin YX, Jiang L, et al. Targeting JAK-STAT signaling to control cytokine release syndrome in COVID-19. Trends Pharmacol Sci. 2020;41(8):531-543.

[51] Gianfranesco M, Hyrich KL, Al-Adely S, et al. Characteristics associated with hospitalisation for COVID-19 in people with rheumatic disease: data from the COVID-19 global rheumatology alliance physician-reported registry. Ann Rheum Dis. 2020;79(7):859-866.

[52] The RECOVERY Collaborative Group. Dexamethasone in Hospitalised Patients with Covid-19 Preliminary Report. NEJM. 2020 [cited 2020 Sept 28]; [11 p.]. DOI:10.1056/NEJMoa2021436

[53] Tesser A, Martins de Carvalho L, Sandrin-Garcia P, et al. Higher interferon score and normal complement levels may identify a distinct clinical subset in children with systemic lupus erythematosus. Arthritis Res Ther. 2020;22(1):91.

[54] Wofsy D. A Tale of Two Trials. Arthritis Rheumatol. 2020;72:1256-1257.

[55] Gamad N, Kakkar AK, Pattanaik S. Efficacy of anifrolumab in systemic lupus erythematosus: a critical analysis of the TULIP trials. Lupus. 2020;29(8):1002-1003.

[56] Putman M. Anifrolumab in Systemic Lupus Erythematosus. N Engl J Med. 2020;382(17):16651666.

[57] Jolly M. How does quality of life of patients with systemic lupus erythematosus compare with that of other common chronic illnesses? J Rheumatol. 2005;32(9):1706-1708.

[58] Alarcón GS, McGwin G Jr, Brooks K, et al. Systemic lupus erythematosus in three ethnic groups. $\mathrm{XI}$. Sources of discrepancy in perception of disease activity: a comparison of physician and patient visual analog scale scores. Arthritis Rheum. 2002;47(4):408-413.

[59] Bermas B, Tassinari M, Clowse $M$, et al. The new FDA labelling rule: impact on prescribing rheumatological medications during pregnancy. Rheumatology (Oxford). 2018;57(suppl 5):v2-v8. [60] Muskardin TLW, Niewold TB. Type I interferon in rheumatic diseases. Nat Rev Rheumatol. 2018;14(4):214-228.

[61] Mok CC. The Jakinibs in systemic lupus erythematosus: progress and prospects. Expert Opin Investig Drugs. 2019;28(1):85-92.

[62] Houssiau F, Thanou A, Mazur M, et al. IFN- $\alpha$ kinoid in systemic lupus erythematosus: results from a phase Ilb, randomised, placebo-controlled study. Ann Rheum Dis. 2020;79(3):347-355. [63] Furie R, Werth V, Merola JF, et al. Monoclonal antibody targeting BDCA2 ameliorates skin lesions in systemic lupus erythematosus. J Clin Invest. 2019;129(3):1359-1371.

[64] Oon S, Wilson NJ, Wicks I. Targeted therapeutics in SLE: emerging strategies to modulate the interferon pathway. Clin Transl Immunology. 2016;5(5):e79.

[65] Morand E, Furie R, Bruce I, et al. Early and sustained responses with anifrolumab treatment in patients with active systemic lupus erythematosus (SLE) in 2 phase 3 trials. Ann Rheum Dis.

2020;79:2-3. (* - analysis of data combined from TULIP-1 and TULIP-2) 


\begin{tabular}{|c|c|c|c|c|c|c|c|c|c|}
\hline $\begin{array}{l}\text { Medica } \\
\text { tion }\end{array}$ & $\begin{array}{l}\text { Trial } \\
\text { name } \\
\text { (NCT } \\
\text { number) }\end{array}$ & $\begin{array}{l}\text { Numb } \\
\text { er of } \\
\text { partici } \\
\text { pants }\end{array}$ & $\begin{array}{l}\text { Patient } \\
\text { popula } \\
\text { tion }\end{array}$ & $\begin{array}{l}\text { Treatme } \\
\text { nt } \\
\text { groups }\end{array}$ & $\begin{array}{l}\text { Active } \\
\text { renal } \\
\text { and/or } \\
\text { neuropsy } \\
\text { chiatric } \\
\text { SLE } \\
\text { included? }\end{array}$ & $\begin{array}{l}\text { Other } \\
\text { trial } \\
\text { features }\end{array}$ & $\begin{array}{l}\text { Primary } \\
\text { endpoin } \\
t\end{array}$ & $\begin{array}{l}\text { Primary } \\
\text { endpoin } \\
t \\
\text { outcom } \\
\text { e }\end{array}$ & $\begin{array}{l}\text { Other } \\
\text { comm } \\
\text { ents }\end{array}$ \\
\hline $\begin{array}{l}\text { Rontaliz } \\
\text { umab } \\
\text { Fully } \\
\text { human } \\
\text { IgG1 } \\
\text { anti- } \\
\text { IFNa }\end{array}$ & $\begin{array}{l}\text { ROSE } \\
\text { (NCT009 } \\
62832 \text { ) } \\
{[29]}\end{array}$ & 238 & $\begin{array}{l}\text { Adults, } \\
\text { moder } \\
\text { ate- } \\
\text { severe } \\
\text { active } \\
\text { SLE, } \\
\text { ANA } \\
\text { positiv } \\
\text { e } \\
\text { (curren } \\
\text { t or } \\
\text { past) }\end{array}$ & $\begin{array}{l}2: 1 \\
\text { randomi } \\
\text { sation to } \\
\text { placebo } \\
\text { ( } n=79) \\
\text { or } \\
\text { rontalizu } \\
\text { mab } \\
750 \mathrm{mg} \\
\text { IV } \\
\text { ( } n=159) \\
\text { in Part 1, } \\
\text { followed } \\
\text { by } \\
\text { placebo } \\
\text { or } \\
\text { rontalizu } \\
\text { mab } \\
200 \text { mg } \\
\text { SC in } \\
\text { Part } 2\end{array}$ & No & $\begin{array}{l}\text { Restrict } \\
\text { ed use } \\
\text { of MMF, } \\
\text { AZA, } \\
\text { and CYC } \\
\text { at } \\
\text { randomi } \\
\text { sation } \\
\text { thus } \\
\text { evaluate } \\
d \text { as } \\
\text { replace } \\
\text { ment } \\
\text { rather } \\
\text { than } \\
\text { add-on } \\
\text { therapy }\end{array}$ & $\begin{array}{l}\text { Reducti } \\
\text { on in all } \\
\text { BILAG A } \\
\text { domains } \\
\text { to BILAG } \\
\text { B or } \\
\text { better, } \\
\text { and } \\
\text { BILAG B } \\
\text { domains } \\
\text { to BILAG } \\
\text { C or } \\
\text { better, } \\
\text { no new } \\
\text { BILAG A, } \\
\text { no }>1 \\
\text { BILAG B, } \\
\text { and no } \\
\text { off- } \\
\text { protocol } \\
\text { rescue } \\
\text { therapy } \\
\text { at Week } \\
24\end{array}$ & $\begin{array}{l}\text { Pooled } \\
\text { IV \& SC: } \\
45.5 \% \\
\text { rontaliz } \\
\text { umab vs } \\
41.8 \% \\
\text { placebo } \\
(p=0.6)\end{array}$ & \\
\hline $\begin{array}{l}\text { Sifalum } \\
\text { umab } \\
\text { Fully } \\
\text { human } \\
\text { IgG1 } \\
\text { anti- } \\
\text { IFNa }\end{array}$ & $\begin{array}{l}\text { NCT0128 } \\
3139 \\
{[28]}\end{array}$ & 431 & $\begin{array}{l}\text { Adults, } \\
\text { moder } \\
\text { ate- } \\
\text { severe } \\
\text { active } \\
\text { SLE, } \\
\text { seropo } \\
\text { sitive, } \\
\text { on SOC }\end{array}$ & $\begin{array}{l}\text { 1:1:1:1 } \\
\text { randomi } \\
\text { sation to } \\
\text { placebo } \\
(108), \\
\text { sifalmu } \\
\text { mab IV } \\
200 \mathrm{mg} \\
(108), \\
600 \mathrm{mg} \\
(109), \\
1200 \mathrm{mg} \\
(107)\end{array}$ & No & & $\begin{array}{l}\text { SRI(4) } \\
\text { respons } \\
\text { e at } \\
\text { week } 52\end{array}$ & $\begin{array}{l}58.3 \% \\
200 \mathrm{mg}, \\
56.5 \% \\
600 \mathrm{mg}, \\
59.8 \% \\
1200 \mathrm{mg} \\
\text { vs } \\
45.4 \% \\
\text { placebo } \\
(p=0.05 \\
7, \\
0.094, \& \\
0.031 \\
\text { respecti } \\
\text { vely) }\end{array}$ & $\begin{array}{l}\text { In } \\
\text { secon } \\
\text { dary } \\
\text { endpo } \\
\text { ints, } \\
\text { sugge } \\
\text { stion } \\
\text { of } \\
\text { clinica } \\
\text { Ily } \\
\text { meani } \\
\text { ngful } \\
\text { differe } \\
\text { nces } \\
\text { in } \\
\text { CLASI } \\
\text { and } \\
\text { joint } \\
\text { count }\end{array}$ \\
\hline $\begin{array}{l}\text { Anifrolu } \\
\text { mab } \\
\text { Fully } \\
\text { human } \\
\text { lgG1 }\end{array}$ & $\begin{array}{l}\text { NCT0296 } \\
2960 \\
{[42]}\end{array}$ & 36 & $\begin{array}{l}\text { Adults, } \\
\text { SLE } \\
\text { with } \\
\text { CLASI } \\
\text { score } \geq \\
10,\end{array}$ & $\begin{array}{l}\text { Randomi } \\
\text { sation to } \\
\text { placebo } \\
\text { ( } n=9 \text { ), } \\
\text { anifrolu } \\
\text { mab SC }\end{array}$ & No & $\begin{array}{l}\text { Explorat } \\
\text { ory } \\
\text { endpoin } \\
\text { t was } \\
\text { efficacy } \\
\text { of SC }\end{array}$ & $\begin{array}{l}\mathrm{PK} \\
\text { (concent } \\
\text { ration of } \\
\text { anifrolu } \\
\text { mab) } \\
\text { and PD }\end{array}$ & $\begin{array}{l}\text { Anifrolu } \\
\text { mab } \\
\text { demons } \\
\text { trated } \\
\text { non- } \\
\text { linear }\end{array}$ & $\begin{array}{l}\text { Obser } \\
\text { ved } \\
\text { PK/PD } \\
\text { profile } \\
\text { similar } \\
\text { to IV }\end{array}$ \\
\hline
\end{tabular}




\begin{tabular}{|c|c|c|c|c|c|c|c|c|c|}
\hline $\begin{array}{l}\text { anti- } \\
\text { IFNaR }\end{array}$ & & & $\begin{array}{l}\text { seropo } \\
\text { sitive, } \\
\text { on } \\
\text { SOC, } \\
\text { high } \\
\text { IFNGS }\end{array}$ & $\begin{array}{l}150 \mathrm{mg} \\
(n=14) \\
\text { or } \\
300 \mathrm{mg} \\
(n=13) \\
\text { every } 2 \\
\text { weeks }\end{array}$ & & $\begin{array}{l}\text { anifrolu } \\
\text { mab on } \\
\text { active } \\
\text { SLE skin } \\
\text { disease } \\
\text { (using } \\
\text { CLASI) }\end{array}$ & $\begin{array}{l}\text { (IFNGS } \\
\text { suppres } \\
\text { sion) at } \\
\text { week } 12\end{array}$ & $\begin{array}{l}\text { PK, and } \\
\text { early } \\
\text { and } \\
\text { sustaine } \\
\text { d IFNGS } \\
\text { suppres } \\
\text { sion }\end{array}$ & $\begin{array}{l}\text { data, } \\
\text { benefi } \\
\text { cial } \\
\text { effect } \\
\text { on } \\
\text { CLASI }\end{array}$ \\
\hline & $\begin{array}{l}\text { MUSE } \\
\text { (NCT014 } \\
38489) \\
{[32]}\end{array}$ & 305 & $\begin{array}{l}\text { Adults, } \\
\text { moder } \\
\text { ate- } \\
\text { severe } \\
\text { active } \\
\text { SLE, } \\
\text { seropo } \\
\text { sitive, } \\
\text { on SOC }\end{array}$ & $\begin{array}{l}1: 1: 1 \\
\text { randomi } \\
\text { sation to } \\
\text { placebo } \\
\text { ( } n=102), \\
\text { anifrolu } \\
\text { mab IV } \\
300 \mathrm{mg} \\
(n=99) \\
\text { or } \\
1000 \mathrm{mg} \\
\text { ( } n=104) \\
\text { every 4 } \\
\text { weeks }\end{array}$ & No & $\begin{array}{l}\text { Steroid } \\
\text { taper } \\
\text { encoura } \\
\text { ged }\end{array}$ & $\begin{array}{l}\text { SRI(4) } \\
\text { respons } \\
\text { e at } \\
\text { week } 24 \\
\text { with } \\
\text { tapering } \\
\text { of OCS } \\
\text { to } \\
\leq 10 \mathrm{mg} / \\
\text { day and } \\
\leq \text { day1 } \\
\text { dose }\end{array}$ & $\begin{array}{l}34.3 \% \\
300 \mathrm{mg}, \\
28.8 \% \\
1000 \mathrm{mg} \\
\text { vs } \\
17.7 \% \\
\text { placebo } \\
(p= \\
0.014 \& \\
p=0.06, \\
\text { respecti } \\
\text { vely) }\end{array}$ & $\begin{array}{l}\text { In } \\
\text { secon } \\
\text { dary } \\
\text { endpo } \\
\text { ints } \\
\text { signifi } \\
\text { cant } \\
\text { reduct } \\
\text { ion } \\
\text { seen } \\
\text { in } \\
\text { CLASI } \\
\text { and } \\
\text { joint } \\
\text { count }\end{array}$ \\
\hline & $\begin{array}{l}\text { TULIP-1 } \\
\text { (NCT024 } \\
46899) \\
{[33]}\end{array}$ & 457 & $\begin{array}{l}\text { Adults, } \\
\text { moder } \\
\text { ate- } \\
\text { severe } \\
\text { active } \\
\text { SLE, } \\
\text { seropo } \\
\text { sitive, } \\
\text { on SOC }\end{array}$ & $\begin{array}{l}2: 1: 2 \\
\text { randomi } \\
\text { sation to } \\
\text { placebo } \\
\text { ( } n=184), \\
\text { anifrolu } \\
\text { mab IV } \\
150 \mathrm{mg} \\
(n=93) \text {, } \\
\text { or } \\
300 \mathrm{mg} \\
(n=180) \\
\text { every } 4 \\
\text { weeks }\end{array}$ & No & $\begin{array}{l}\text { Mandat } \\
\text { ory } \\
\text { steroid } \\
\text { taper if } \\
\text { on } \\
>10 \mathrm{mg} \\
\text { at } \\
\text { baseline } \\
\text {, NSAIDs } \\
\text { consider } \\
\text { ed } \\
\text { restricte } \\
d \\
\text { medicati } \\
\text { ons that } \\
\text { would } \\
\text { lead to } \\
\text { NR if } \\
\text { comme } \\
\text { nced }\end{array}$ & $\begin{array}{l}\text { SRI(4) } \\
\text { respons } \\
\text { e at } \\
\text { week } 52\end{array}$ & $\begin{array}{l}38 \% \\
150 \mathrm{mg}, \\
36.2 \% \\
300 \mathrm{mg} \\
\text { vs } \\
40.4 \% \\
\text { placebo } \\
(p=N C \& \\
p=0.41, \\
\text { respecti } \\
\text { vely) }\end{array}$ & $\begin{array}{l}\text { In } \\
\text { secon } \\
\text { dary } \\
\text { endpo } \\
\text { ints, } \\
\text { sugge } \\
\text { stion } \\
\text { of } \\
\text { clinica } \\
\text { lly } \\
\text { meani } \\
\text { ngful } \\
\text { differe } \\
\text { nces } \\
\text { in } \\
\text { CLASI, } \\
\text { joint } \\
\text { count } \\
\text { and } \\
\text { BICLA }\end{array}$ \\
\hline & $\begin{array}{l}\text { TULIP-2 } \\
\text { (NCT024 } \\
46912 \text { ) } \\
{[34]}\end{array}$ & 362 & $\begin{array}{l}\text { Adults, } \\
\text { moder } \\
\text { ate- } \\
\text { severe } \\
\text { active } \\
\text { SLE, } \\
\text { seropo } \\
\text { sitive, } \\
\text { on SOC }\end{array}$ & $\begin{array}{l}1: 1 \\
\text { randomi } \\
\text { sation to } \\
\text { placebo } \\
\text { ( } n=182) \\
\text { or } \\
\text { anifrolu } \\
\text { mab IV } \\
300 \mathrm{mg} \\
\text { ( } n=180) \\
\text { every } 4 \\
\text { weeks }\end{array}$ & No & $\begin{array}{l}\text { Mandat } \\
\text { ory } \\
\text { steroid } \\
\text { taper if } \\
\text { on } \\
>10 \mathrm{mg} \\
\text { at } \\
\text { baseline } \\
\text { ' } \\
\text { protocol } \\
\text { amend } \\
\text { ment: } \\
\text { NSAID } \\
\text { no }\end{array}$ & $\begin{array}{l}\text { BICLA } \\
\text { respons } \\
\text { e at } \\
\text { week } 52 \\
\text { (protoco } \\
\text { I } \\
\text { amend } \\
\text { ment } \\
\text { made } \\
\text { from } \\
\text { SRI(4)) } \\
\text { on } \\
\text { reviewin } \\
\text { g results }\end{array}$ & $\begin{array}{l}47.8 \% \\
300 \mathrm{mg} \\
\text { vs } \\
31.5 \% \\
\text { placebo } \\
(p=0.00 \\
1)\end{array}$ & $\begin{array}{l}\text { In } \\
\text { secon } \\
\text { dary } \\
\text { endpo } \\
\text { ints } \\
\text { there } \\
\text { were } \\
\text { clinica } \\
\text { lly } \\
\text { signifi } \\
\text { cant } \\
\text { differe } \\
\text { nces } \\
\text { in }\end{array}$ \\
\hline
\end{tabular}




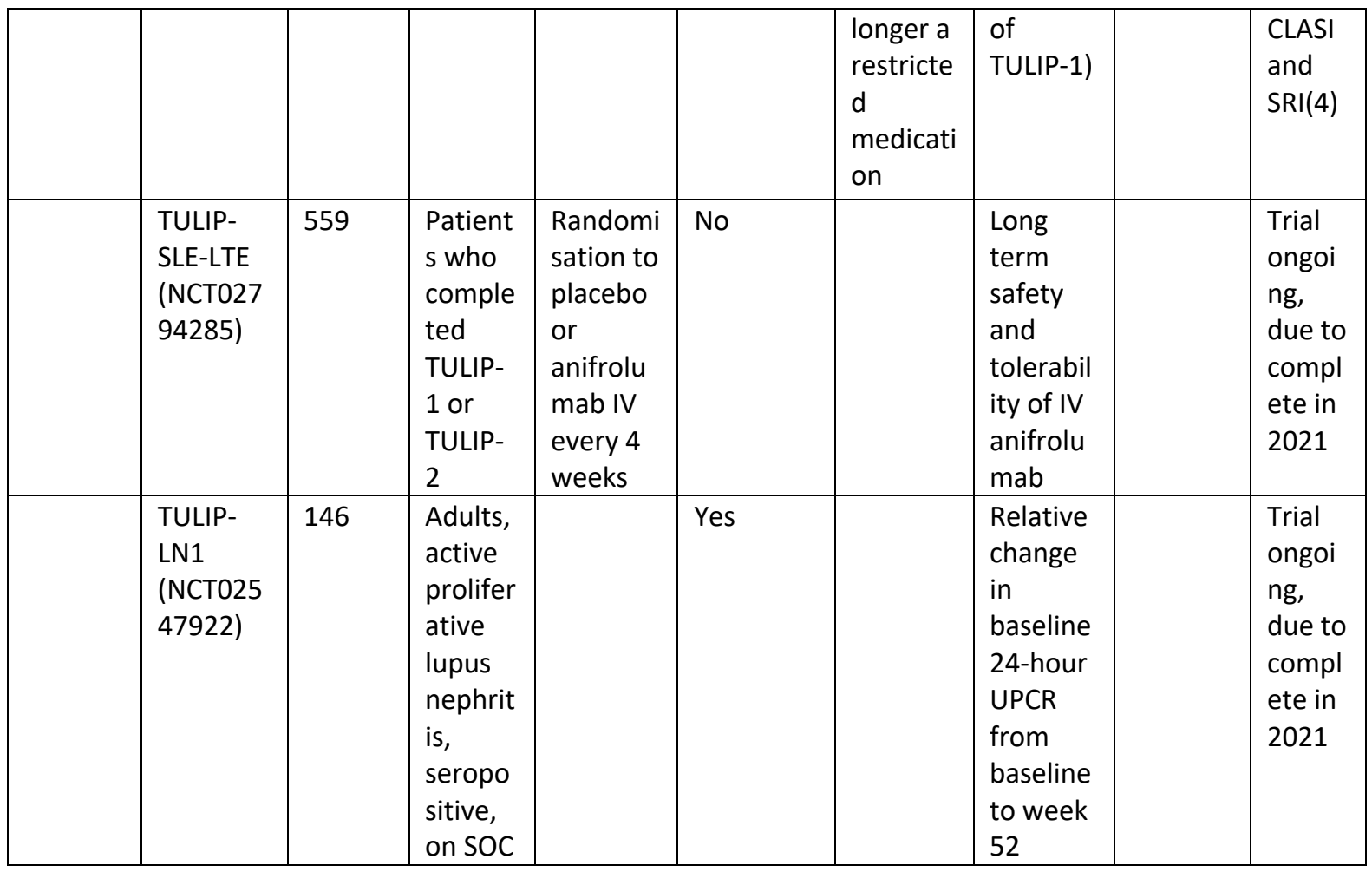

Table 1: Summary of phase II and III studies of anti-IFN $\alpha$ and anti-IFN $\alpha$ receptor monoclonal antibodies.

AZA = azathioprine, $C Y C=$ cyclophosphamide, $\mathrm{BICLA}=\mathrm{BILAG}$ based composite lupus assessment, BILAG = British Isles Lupus Assessment Group, CLASI = cutaneous LE disease area and severity index, IFNGS = interferon gene signature, IV = intravenous, $\mathrm{MMF}=$ mycophenolate mofetil, $\mathrm{NC}=$ not calculated, NSAID = non-steroidal anti-inflammatory drug, $\mathrm{OCS}=$ oral corticosteroid, $\mathrm{SC}=$ subcutaneous, $S O C=$ standard of care, UPCR = urine protein to creatinine ratio; "seropositive" indicates ANA, anti-dsDNA or anti-Sm positive. 